\title{
Livestock predation by jaguars Panthera onca in south-eastern Mexico: the role of local peoples' practices
}

\author{
Juan L. Peña-Mondragón, Alicia Castillo, Almira Hoogesteijn \\ and ENRIQUE MARTÍNEZ-MEYER
}

\begin{abstract}
Inadequate livestock husbandry practices threaten the maintenance of global biodiversity and provoke conflicts between people and wildlife, and large carnivorous mammals are among the most affected. The jaguar Panthera onca is one of the most threatened species in the Americas, being targeted by livestock producers who suffer economic losses as a result of predation. The way in which rural producers in countries such as Mexico conduct husbandry practices may influence levels of predation by jaguars. Our objective was to understand how such practices are conducted in the Selva Lacandona in south-eastern Mexico, to identify their influence on the vulnerability of livestock to predation by jaguars. We characterized local husbandry practices through participant observation, interviews and surveys. Our results show that the most important practices that make livestock vulnerable to predation include the location of grazing lands close to forested areas and water sources, the absence of practices for the proper disposal of carcasses, and poor control of calving and care of calves. Our recommendations include monitoring of livestock movements and synchronization of calving. Economic investment and behavioural change can be accomplished through capacity building and providing people with the means to monitor and manage their livestock. Small actions can reduce livestock losses and improve the economic circumstances of rural people, and thus increase their tolerance and respect towards jaguars.
\end{abstract}

Keywords Human-carnivore conflict, jaguar, livestock husbandry, Mexico, Panthera onca, social-ecological approach, vulnerability to predation

To view supplementary material for this article, please visit http://dx.doi.org/10.1017/So030605315001088

Juan L. Peña-Mondragón and Alicia Castillo (Corresponding author) Laboratorio de Socioecología y Comunicación para la Sustentabilidad, Instituto de Investigaciones en Ecosistemas y Sustentabilidad, Universidad Nacional Autónoma de México, Antigua Carretera a Pátzcuaro 8701 Col Sn. José de la Huerta, C.P. 58190, Morelia, Michoacán, Mexico

E-mail castillo@cieco.unam.mx

Almira Hoogesteijn Laboratorio de Salud Ambiental, Departamento de Ecología Humana del CINVESTAV-IPN (Unidad Mérida), Mérida, Yucatán, Mexico

Enrique Martínez-Meyer Instituto de Biología, Universidad Nacional Autónoma de México, Coyoacán, 04510 Ciudad de México, Distrito Federal, Mexico

Received 18 May 2015. Revision requested 24 June 2015.

Accepted 26 August 2015. First published online 18 February 2016.

\section{Introduction}

T arge carnivores play an important role in ecological 1 processes. They affect the density and dynamics of prey species, with cascade effects on ecosystems (Ripple et al., 2014). Habitat fragmentation disturbs the behaviour of carnivores with large home ranges (Woodroffe, 2000), and brings them into conflict with people (Thirgood et al., 2005). Inadequate livestock husbandry is considered a major threat in this regard, particularly in non-industrialized countries (Hull et al., 2014) where livestock production is badly managed (Ripple et al., 2014). On the American continent, jaguars Panthera onca are considered to be a threat to livestock, and conflicts between rural communities and jaguars are common (Caso et al., 2008; Peña-Mondragón \& Castillo, 2013). In Mexico the jaguar has been extirpated from $60 \%$ of its original distribution (Chávez \& Ceballos, 2006); meanwhile livestock production has developed extensively (Chauvet, 2001), and in 2003 cattle occupied 110 million ha (INE, 2004). The land occupied by jaguars is owned by rural inhabitants, with $60-70 \%$ of Mexico's forested areas owned by indigenous and mestizo communities (Bezaury-Creel \& Gutiérrez Carbonell, 2008). The term peasant is commonly used (corresponding to campesino in Spanish) to refer to these groups, and denotes a way of living that includes multiple uses of natural resources.

The tropical rainforest of the Selva Lacandona in the state of Chiapas is a priority site for jaguar conservation in Mexico (Chávez \& Ceballos, 2006), although illegal hunting occurs throughout the species' range in Mexico (AmadorAlcalá et al., 2013). In 1978 the 3,312 ha Montes Azules Biosphere Reserve was designated to secure the long-term maintenance of regional biodiversity (SEMARNAP, 2000). Agriculture and livestock production are important livelihood activities in the region, with the latter representing one of the main sources of income for rural people. Thus, perceived and actual predation of livestock by jaguars puts the species at risk of persecution and elimination (SEMARNAT, 2009). Although predation of livestock by large mammals has been widely studied (Conforti \& Azevedo, 2003; Hoogesteijn \& Hoogesteijn, 2008; Rumiz et al., 2011; Peña-Mondragon \& Castillo, 2013) it remains unclear which livestock husbandry practices may trigger predation. If livestock husbandry influences levels of predation by carnivores such as jaguars, there is clearly a need to understand the motivations and needs of the people 


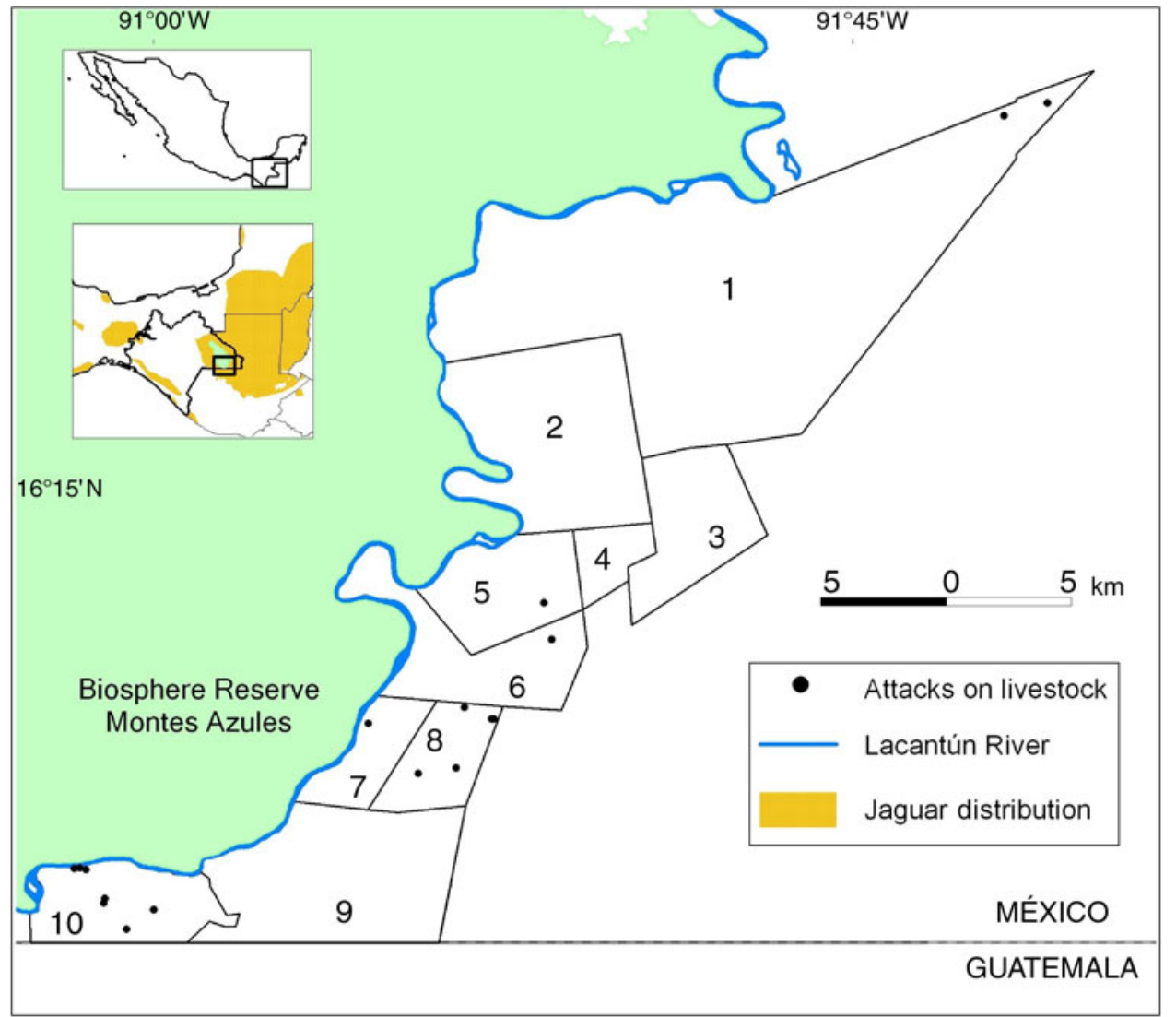

FIG. 1 Sites where livestock were attacked by jaguars Panthera onca in ejidos adjacent to the Montes Azules Biosphere Reserve, in the Mexican state of Chiapas. 1, Zamora Pico de Oro; 2, Reforma Agraria; 3, Nuevo San Isidro; 4, López Portillo; 5 , Adolfo López Mateos; 6, Galacia; 7, Playón de la Gloria; 8, Flor Marques; 9, Boca Chajúl; 10, Loma Bonita. involved, and the various aspects of their practices. Thus our main objective was to characterize livestock husbandry practices to identify those that increase the risk of predation of livestock by jaguars in the rural communities adjacent to the Montes Azules Biosphere Reserve.

\section{Study area}

The study was conducted in 'ejidos' (a system of land tenure that combines individual and communal possession; Warman, 2001) adjacent to the Montes Azules Biosphere Reserve in the Selva Lacandona (Fig. 1), which hosts a high diversity of Neotropical flora and fauna (Miller et al., 2001). Deforestation rates of up to $33 \%$ were recorded in the study area during 1986-2010 (Carabias et al., 2010). Culturally, the Selva Lacandona comprises indigenous and mestizo communities, which have migrated there since the beginning of the 2oth century, mainly from the mountainous regions of Chiapas (De Vos, 1988). The Reserve is important for jaguar conservation (Chávez \& Ceballos, 2006) but there may be only 51-132 individuals remaining there (de la Torre \& Medellín, 2011).

\section{Methods}

We used a socio-ecological systems research approach (Berkes \& Folke, 2000). As our questions were related to human practices we used research instruments from the social sciences applied to the environmental sciences (Supplementary Material 1; Newing et al., 2011). We also collected ecological information related to the identification of sites of livestock predation and landscape fragmentation, to construct an overview of the human-jaguar conflict.

We conducted four exploratory visits during 2008-2010. As a first step, following our ethical code of conduct, we explained the project to local people and asked the local authorities for permission to conduct the research. Gaining trust and empathy was essential, as jaguars are a protected species and their elimination is sanctioned with fines and prison sentences (Tarrés, 2004). We collected data during five 20-day visits, in February and October 2011, March and September 2012 and January 2013, using participant observation, surveys (closed-ended questionnaires) and semistructured interviews in which we asked open questions and allowed participants to talk freely (Table 1; Taylor \& Bogdan, 1987; Patton, 2002). For practical purposes the surveys and interviews were integrated into a single instrument, and we recorded the answers to both types of questions on a form. Localities were selected based on evidence of jaguar presence nearby; key actors were identified as those whose livestock had been attacked by jaguars. Thirty-two heads of families agreed to participate in the study; these were enlisted using the snowball sampling method (Newing et al., 2011), where participants were asked to refer others who 
TABLE 1 Methods used for data collection.

\begin{tabular}{ll}
\hline Method & Objective \\
\hline $\begin{array}{l}\text { Informal talks in the com- } \\
\text { munity (Sanchez, 2004) }\end{array}$ & $\begin{array}{l}\text { To establish initial contact with } \\
\text { local people, gain access to the } \\
\text { community \& identify stakeholders } \\
\text { To record observations, events \& } \\
\text { daily activities in relation to live- } \\
\text { stock management (including } \\
\text { (Sanchez, 2004) }\end{array}$ \\
$\begin{array}{l}\text { talking to people while participat- } \\
\text { ing in local activities) } \\
\text { To obtain information regarding } \\
\text { Surveys (Hernández- }\end{array}$ & $\begin{array}{l}\text { specific aspects of cattle herds, } \\
\text { economic investments, products \& } \\
\text { derivatives } \\
\text { To obtain detailed information re- } \\
\text { garding processes, motivations \& }\end{array}$ \\
Semi-structured interviews & $\begin{array}{l}\text { needs of producers, which is diffi- } \\
\text { cult to obtain through surveys }\end{array}$ \\
\hline Sierra, 1998) &
\end{tabular}

may have had similar problems. People were willing to talk and were open to providing information. During the fieldwork 17 attacks on livestock by jaguars were confirmed through examining carcasses (Fig. 1).

Data analysis consisted of quantifying responses to specific closed-ended questions, and constructing categories based on the responses provided to open questions (Strauss, 1995; Newing et al., 2011). The categories are intended to reflect the ideas and actions of people according to their own perspectives, motivations and needs. Frequencies and percentages were calculated for each category. As participants could give more than one response to the same question, in some cases the percentages exceed $100 \%$. A first analysis consisted of spatially locating each category of livestock practices reported. A qualitative indicator of the vulnerability of livestock to predation by jaguars was constructed to identify the variables involved and their relative importance, which was useful for informing recommendations (Table 2). Forage, capture and prey consumption were the three elements used to determine whether vulnerability was high, medium or low, following optimal foraging theory (Gutiérrez, 1998). A value was then assigned for each activity involved in livestock management.

\section{Results}

Figure 2 relates livestock practices with the type of surroundings where these take place (i.e. human settlement, corral, pastureland, border or transition zone, or tropical rain forest). Decisions concerning issues such as the location of family plots and rainforest units are taken at the ejido community level. In the corral zone, animals may be removed and kept closer to the family home to avoid the spread of disease or attacks by predators. Livestock are grazed on plots of pasture delimited by barbed wire fences, which in some cases are adjacent to borders or transition areas with forest patches. Livestock reproduction occurs in the corral and pasture units. Livestock move within border zones and forested lands to obtain water from streams or natural springs.

The various aspects of livestock husbandry practices are illustrated in Fig. 3. Four broad themes emerge from the data: (1) general aspects of livestock practices, (2) herd improvement, (3) economic income, and (4) economic losses. These themes encapsulate the main aims of rural families in raising livestock: to increase production and economic income to improve their well-being.

More than half of those interviewed (62\%) had subdivisions within their fenced grazing areas, and rotated livestock every 15-30 days within each subdivision. Access to water for livestock was limited to natural sources such as rivers, streams and springs, which are abundant in the area; all participants expressed a commitment not to log trees, and to protect vegetation surrounding sites that provided water. The disposal of animal waste was another important aspect of animal husbandry; dead animals were left where they were found and were not buried or burned. Reproduction was carried out through free mounting, in which a male is released close to females. Sometimes directed mounting was carried out with a borrowed male stud. Reproduction was conducted in corrals and in the grazing zones (Fig. 2). None of the interviewees reported a schedule of vaccinations, and veterinary assistance would be sought only after considerable losses had occurred. Only $18 \%$ of interviewees had control of their herd (by means of ear tags or burn marks); $46 \%$ reported individual numbering of each head of livestock, mainly to meet the requirements of governmental assistance programmes, such as the Program of Stimuli for Livestock Productivity. Ear tags or brands are used to identify individuals within a herd. In relation to infrastructure, possession of corrals (59\%) and internal subdivisions (50\%) were most commonly reported by interviewees (Table 3).

Herd improvement Herd improvement is based on nutrition, and the only food supplement interviewees could provide was mineral salt. Stud males, used to maintain the genetic health of livestock herds, are acquired at livestock auctions or are loaned from other producers (Table 3). Females are returned to their reproductive condition through early weaning of calves, and are crossed with a new male.

Family income Families seek to increase their herds to sell animals or derivatives. For $96 \%$ of interviewees, live animals $<6$ months of age were the most lucrative product; only $6 \%$ of respondents produced milk and cheese. Other sources of income included economic support from governmental agencies (21\% of interviewees) and self-employment (12\%). Families also engaged in agricultural activities such as the cultivation of maize ( $71 \%)$ and beans ( $75 \%$; Table 3$)$. 
TABLE 2 Indicator of vulnerability of livestock to predation in relation to various management activities, with recommendations for mitigation, and the type of change needed.

\begin{tabular}{|c|c|c|c|c|c|c|}
\hline \multirow[b]{2}{*}{$\begin{array}{l}\text { Management } \\
\text { activity }\end{array}$} & \multicolumn{4}{|c|}{ Indicator of vulnerability $^{1}$} & \multirow[b]{2}{*}{ Recommendations for mitigation } & \multirow[b]{2}{*}{$\begin{array}{l}\text { Type of changes } \\
\text { needed }\end{array}$} \\
\hline & $\begin{array}{l}\text { Easy } \\
\text { access }\end{array}$ & $\begin{array}{l}\text { Easy } \\
\text { capture }\end{array}$ & $\begin{array}{l}\text { Quick } \\
\text { consumption }\end{array}$ & $\begin{array}{l}\text { Vulnerability } \\
\text { level }^{2}\end{array}$ & & \\
\hline $\begin{array}{l}\text { Livestock grazing } \\
\text { areas near con- } \\
\text { served forests }\end{array}$ & 3 & 3 & 3 & High & $\begin{array}{l}\text { Relocate grazing areas away from } \\
\text { forested lands. If this is not possible, } \\
\text { create a double perimeter fence in } \\
\text { areas adjacent to forested areas. }\end{array}$ & $\begin{array}{l}\text { Economic } \\
\text { investment }\end{array}$ \\
\hline $\begin{array}{l}\text { Cattle drink water in } \\
\text { riparian zones }\end{array}$ & 3 & 3 & 2 & High & $\begin{array}{l}\text { Build drinking troughs away from ri- } \\
\text { parian areas; water can be extracted } \\
\text { from streams \& moved through gravity } \\
\text { systems. }\end{array}$ & $\begin{array}{l}\text { Economic } \\
\text { investment }\end{array}$ \\
\hline $\begin{array}{l}\text { Inappropriate hand- } \\
\text { ling of cattle } \\
\text { carcasses }\end{array}$ & 3 & 3 & 2 & High & Bury or burn livestock carcasses. & $\begin{array}{l}\text { Behavioural } \\
\text { change }\end{array}$ \\
\hline $\begin{array}{l}\text { No control of re- } \\
\text { production \& } \\
\text { births }\end{array}$ & 2 & 2 & 2 & Medium & $\begin{array}{l}\text { Synchronize mating seasons for better } \\
\text { control of births. }\end{array}$ & $\begin{array}{l}\text { Behavioural } \\
\text { change }\end{array}$ \\
\hline $\begin{array}{l}\text { Poor veterinary } \\
\text { supervision }\end{array}$ & 2 & 2 & 1 & Medium & $\begin{array}{l}\text { Establish vaccine schedules. Carry out } \\
\text { veterinary monitoring of herds } \\
\text { throughout the year. }\end{array}$ & $\begin{array}{l}\text { Behavioural } \\
\text { change }\end{array}$ \\
\hline Poor control of herd & 2 & 1 & 1 & Medium & $\begin{array}{l}\text { Establish adequate recording of sales, } \\
\text { deaths, births, \& losses from various } \\
\text { causes. }\end{array}$ & $\begin{array}{l}\text { Behavioural } \\
\text { change }\end{array}$ \\
\hline Poor handling & 1 & 1 & 1 & Low & $\begin{array}{l}\text { Keep mature females with experience } \\
\text { in defending their calves. Avoid } \\
\text { dehorning. }\end{array}$ & $\begin{array}{l}\text { Behavioural } \\
\text { change }\end{array}$ \\
\hline $\begin{array}{l}\text { Poor infrastructure } \\
\text { for mitigating } \\
\text { livestock } \\
\text { predation }\end{array}$ & 2 & 1 & 0 & Low & $\begin{array}{l}\text { Invest in perimeter fencing to improve } \\
\text { separation between pasture lands \& } \\
\text { forested areas. Invest in nocturnal } \\
\text { confinement corrals to protect young } \\
\text { animals. }\end{array}$ & $\begin{array}{l}\text { Economic } \\
\text { investment }\end{array}$ \\
\hline $\begin{array}{l}\text { Nutritional } \\
\text { management }\end{array}$ & 2 & 2 & 0 & Medium & $\begin{array}{l}\text { Invest in food supplements that fortify } \\
\text { animals. When possible, use native } \\
\text { forage plants as supplements. }\end{array}$ & $\begin{array}{l}\text { Economic } \\
\text { investment }\end{array}$ \\
\hline $\begin{array}{l}\text { Fertility } \\
\text { management }\end{array}$ & 1 & 1 & 0 & Low & $\begin{array}{l}\text { Do not wean early. Seek veterinary } \\
\text { advice to establish strategies for fertil- } \\
\text { ity increase. }\end{array}$ & $\begin{array}{l}\text { Behavioural } \\
\text { change }\end{array}$ \\
\hline Sourcing of stallions & 0 & 1 & 0 & Low & $\begin{array}{l}\text { Source males from various places to } \\
\text { improve genetic pools. }\end{array}$ & $\begin{array}{l}\text { Economic invest- } \\
\text { ment \& behav- } \\
\text { ioural change }\end{array}$ \\
\hline
\end{tabular}

${ }^{1} \mathrm{O}$, no influence; 1 , low influence; 2 , medium influence; 3 , high influence

${ }^{2}$ Sum of vulnerability indicators: $1-3$, low; 4-6, medium; 7-9, high vulnerability

Economic loss Diseases were perceived to be one of the main factors affecting livestock production; $56 \%$ of interviewees reported rabies (viral encephalomyelitis) and 50\% reported anthrax (Bacillus sp.). Predators were another relevant factor in economic losses, according to 50\% of interviewees. Although we did not ask directly about livestock theft, as it is a sensitive subject, it was mentioned by at least 15 interviewees (Table 3).

Vulnerability to predation The management practices that expose livestock to risk of predation by jaguars are outlined in Table 2. The qualitative indicator of livestock vulnerability allows us to identify factors that impede or restrict changes in practices that could mitigate predation.

\section{Discussion}

Few studies have examined the role of rural peoples' livestock practices in relation to predation by jaguars. Our field experience indicates that the conflict is accepted among rural inhabitants, government authorities and conservationists working in the Selva Lacandona region. However, campaigns and mitigation programmes have been conducted 


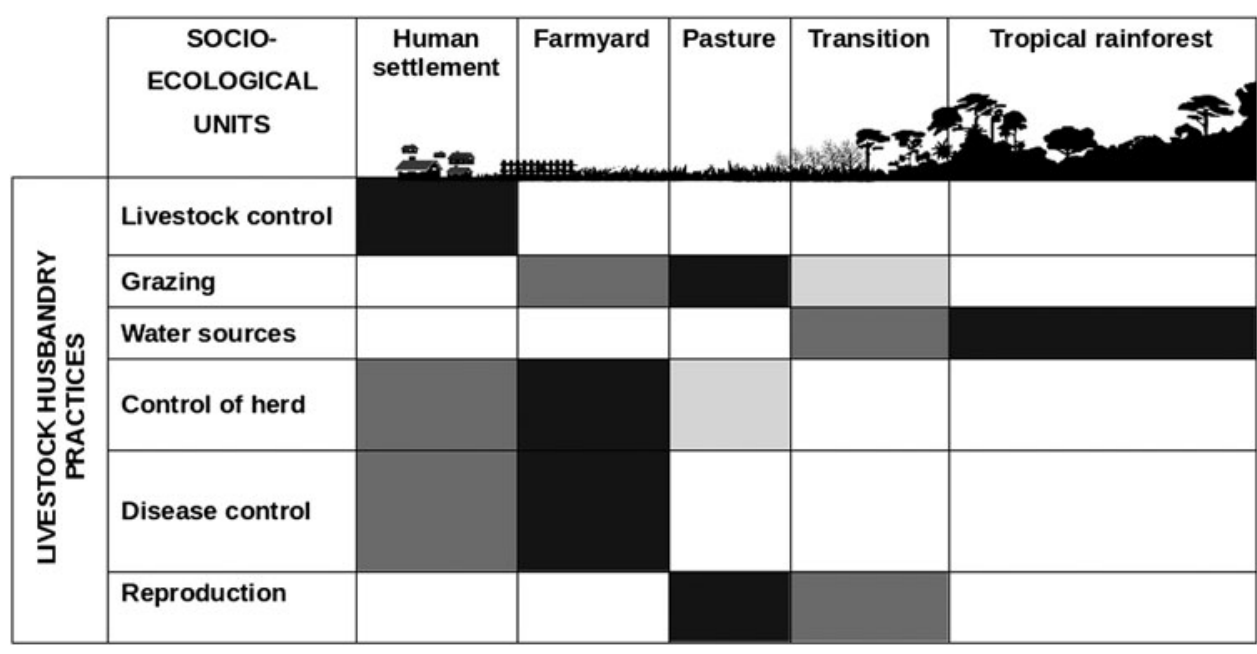

FIg. 2 Spatial distribution of the major components of livestock practices in ejidos adjacent to the Montes Azules Biosphere Reserve (Fig. 1). The shading indicates the intensity of the activity (black, high intensity; dark grey, medium intensity; light grey, low intensity).

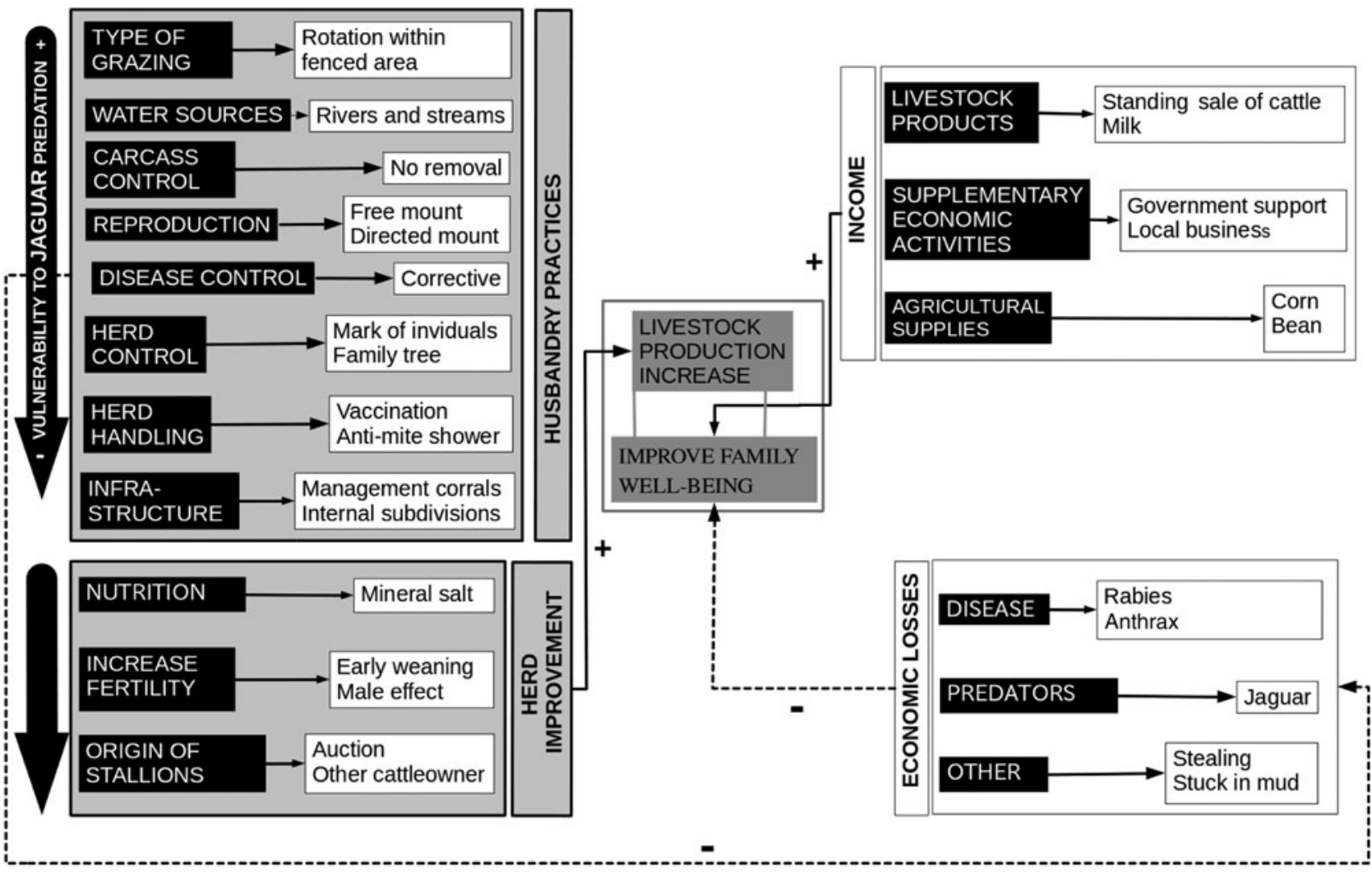

FIG. 3 Categories and specific practices relating to general livestock husbandry, herd improvement, income and economic losses in south-eastern Mexico (Table 3), and the relationships between them (solid and dashed lines represent positive and negative relationships, respectively). The categories within the grey-shaded boxes correspond to management practices that affect livestock predation by jaguars, and those within white boxes indicate responses of interviewees.

without a deep understanding of the views of those affected by the conflict. Our results may be restricted to the Selva Lacandona region but the context of our study is similar to that in other places in Mexico, as well as in Central and South America (Burgas et al., 2014; Tortato et al., 2015).

Livestock grazing near well-preserved portions of jaguar habitat has been reported as a major cause of predation throughout the jaguar's natural range (Azevedo \& Murray, 2007; Palmeira et al., 2008; Donikar et al., 2011; SotoShoender \& Giuliano, 2011; Garrote, 2012; Zarco-González et al., 2013; Soh et al., 2014). We also identified this pattern, with cattle becoming vulnerable to predation when they move near natural areas to obtain food and water. Another factor that contributes to livestock vulnerability is 
TABLE 3 Categories and specific practices relating to the general management of livestock, herd improvement, income and economic losses, with the percentage of interviewees $(n=32)$ who used each practice.

\begin{tabular}{|c|c|c|}
\hline Category & Specific practices & $\%$ \\
\hline \multicolumn{3}{|l|}{ General management of livestock } \\
\hline \multirow[t]{2}{*}{ Type of grazing } & Free within fenced area & 100 \\
\hline & Grazing rotation & 62.5 \\
\hline Water sources & Rivers \& streams & 100 \\
\hline \multirow[t]{2}{*}{ Carcass control } & Carcasses not moved & 81.25 \\
\hline & Moved when useful & 18.75 \\
\hline \multirow[t]{2}{*}{ Reproduction } & Free mount & 100 \\
\hline & Mount directed & 3.12 \\
\hline Disease control & When necessary (corrective) & 100 \\
\hline \multirow[t]{5}{*}{ Herd control } & Individual marking & 46.87 \\
\hline & Family tree & 25 \\
\hline & Written control & 25 \\
\hline & Record of individuals & 18.75 \\
\hline & Record of deaths & 9.37 \\
\hline \multirow[t]{4}{*}{ Handling of herd } & Vaccination & 100 \\
\hline & Anti-mite shower & 100 \\
\hline & Dehorning & 37.37 \\
\hline & Castration & 12.5 \\
\hline \multirow[t]{6}{*}{ Infrastructure } & Management corrals & 59.37 \\
\hline & Internal subdivisions & 50 \\
\hline & Internal roads & 46.87 \\
\hline & Feeders & 43.75 \\
\hline & Night corrals & 12 \\
\hline & Barns & 6.25 \\
\hline \multicolumn{3}{|l|}{ Herd improvement } \\
\hline Nutrition & Mineral salt & 100 \\
\hline \multirow[t]{3}{*}{ Fertility increase } & Early weaning & 50 \\
\hline & Male effect & 12.5 \\
\hline & Hormonal & 9.37 \\
\hline \multirow[t]{3}{*}{ Origin of stallion } & Auction & 46.87 \\
\hline & Other cattle owner & 46.87 \\
\hline & Own & 21.87 \\
\hline \multicolumn{3}{|l|}{ Income } \\
\hline \multirow{3}{*}{ Livestock products } & Sale of cattle & 96.87 \\
\hline & Milk & 6.05 \\
\hline & Cheese & 6.25 \\
\hline \multirow[t]{5}{*}{ Supplementary economic activities } & Workforce & 3.12 \\
\hline & Government support & 21.87 \\
\hline & Local business & 12.5 \\
\hline & Local transport & 3.12 \\
\hline & Temporary employment & 3.12 \\
\hline \multirow[t]{6}{*}{ Agricultural supplies } & Corn & 75 \\
\hline & Subsistence & 75 \\
\hline & Sale & 50 \\
\hline & Bean & 71.8 \\
\hline & Subsistence & 71.8 \\
\hline & Sale & 53 \\
\hline \multicolumn{3}{|l|}{ Economic losses } \\
\hline \multirow[t]{5}{*}{ Disease } & Rabies (viral encephalomyelitis) & 56.25 \\
\hline & Anthrax (Bacillus anthracis) & 50.5 \\
\hline & Malignant edema (Clostridium septicum) & 37.5 \\
\hline & Blackleg (Clostridium chauvoei) & 21.87 \\
\hline & Dehydration & 3.12 \\
\hline \multirow[t]{2}{*}{ Predators } & Jaguar Panthera onca & 50 \\
\hline & Theft & \\
\hline \multirow[t]{2}{*}{ Other } & Stuck in mud & 9.37 \\
\hline & Attack by vultures & 3.12 \\
\hline
\end{tabular}


the handling of dead animals. In the study area carcasses are not removed, and this can encourage carnivores to attack livestock, and may even create some dependency or preference for livestock as a source of food (Hoogesteijn \& Hoogesteijn, 2011). Thus incineration or burying of dead animals is a recommended practice (Sander et al., 2002; Hoogesteijn \& Hoogesteijn, 2011). Proper handling of reproduction activities and management of calves are also important factors in reducing predation by carnivores (Schiess-Meier et al., 2007). Providing special confinement corrals for vulnerable young calves $(<6$ months) provides security (Van Bommel et al., 2007; Hoogesteijn \& Hoogesteijn, 2011) and facilitates vigilance by livestock keepers.

A relevant issue that emerged is the need for a written record of every animal that is sold or has died, whether by natural or other causes (e.g. disease, drowning, snake bite or attack by a predator). This practice was not evident in our study, resulting in overestimation of the damage caused by jaguars (Hoogesteijn \& Hoogesteijn, 2011). We found that the approach to disease management was remedial rather than preventive, and this behaviour has been passed down through generations. Good health management results in fewer losses at birth and in general, which in turn increases productivity, and thus losses caused by predation are not as devastating to the family economy. In most cases livestock losses to predators are fewer than those caused by other factors, including disease (Hoogesteijn \& Hoogesteijn, 2011). At present, disease management is mostly confined to vaccination programmes administered by government agencies. This economic incentive accompanied by an educational campaign could raise awareness of the benefits of more efficient livestock practices.

Early weaning is a harmful practice used to increase animal production. It is not recommended as it can lead to low meat production; a young calf left with its mother can be more productive (Arias et al., 1998). It can also lead to digestive and respiratory illnesses, as well as diseases related to poor adaptation as a result of weak body state and/or retarded growth (Soni, 1998). Thus, early weaning produces weaker individuals that may be more susceptible to diseases, and vulnerable to predation by carnivores such as the jaguar. Changing this practice will require training to ensure that producers understand the infrastructure required for the appropriate management of both mothers and young.

Livestock production in the Selva Lacandona represents a source of complementary income for families, as in other parts of Mexico and elsewhere (FAO, 2009; Davies et al., 2010). There is a need to supplement the family economy with governmental support and subsistence agriculture partly because livestock production does not provide the yields expected. However, this creates a circular problem: because livestock does not provide the necessary earnings people do not invest in better management of their livestock, although this would increase their returns in the long term.
Taking into account factors such as disease and predation, livestock production becomes an activity that requires high levels of investment, which is impossible for the majority of families in the Selva Lacandona. Livestock theft must also be evaluated as it results in significant losses for producers, as has occurred in South America (Hoogesteijn \& Arenas-Avella, 2008).

A broad conclusion derived from our findings is that several specific livestock husbandry practices make herds in the Selva Lacandona more vulnerable to attack by jaguars (these practices and our recommendations are outlined in Table 2). Two broad types of changes were identified to implement these recommendations: (1) economic investment, and (2) behavioural changes in communities and in relation to the cultural and educational histories of families. Both matters require technical and communication interventions, with the provision of financial support. Mitigation programmes already in existence should consider not only a payment for animals lost in attacks by carnivores (which is helpful) but also the implementation of a more integral strategy that includes a capacity-building perspective (Abella \& Fogel, 2000). Training workshops that provide technical advice should be accompanied by visual educational materials designed for people with poor literacy skills or who have little experience of using written materials. Provision of certificates for good livestock practices may help people to get access to economic support and resources such as materials for fences or veterinary assistance. One important recommendation relates to the monitoring of livestock herds. We advise the use of written records of all livestock, which could be maintained by marking in special notebooks designed for those with a low level of literacy (Supplementary Fig. S1).

Finally, we recommend that agents such as the government and NGOs provide educational interventions (awareness-raising and training) as well as economic support to help families improve their livestock husbandry practices. Conversion to efficient and productive practices would improve families' economic circumstances, which could translate into greater investment in infrastructure and veterinary care, and ultimately increase productivity. Such actions can be effective in mitigating conflict, and may create a scenario of greater tolerance for jaguars in the Selva Lacandona.

\section{Acknowledgements}

This paper constitutes a partial fulfilment of the Graduate Programme in Biological Science (Posgrado en Ciencias Biológicas) of the National Autonomous University of Mexico (UNAM). AC acknowledges the $\mathrm{PhD}$ scholarship received from the National Council of Science and Technology (CONACYT) and the support received from the Instituto de Investigaciones en Ecosistemas y Sustentabilidad of UNAM. 
Funding was provided by Idea Wild, Cleveland Metroparks Zoo and the Cleveland Zoological Society. We thank Keith MacMillan and Mary-Ann Hall for editing the English. We are especially grateful to all those in the rural communities who kindly participated in this research.

\section{References}

Abella, G. \& Fogel, R. (200o) Principios de intervención en la capacitación comunitaria. Naciones Unidas PNUMA, Mexico.

Amador-Alcalá, S., Naranjo, E.J. \& Jiménez-Ferrer, G. (2013) Wildlife predation on livestock and poultry: implications for predator conservation in the rainforest of south-east Mexico. Oryx 47, 243-250.

Arias, A.A., Revidatti, M., Slobodzian, A., Capellari, A. \& Benítez, O. (1998) Diferencias en la ganancia de peso atribuibles al destete precoz en terneros cruza en el NO de Corrientes. Revista Argentina de Producción Animal, 18, 240.

Azevedo, F.C.C. \& Murray, D.L. (2007) Evaluation of potential factors predisposing livestock to predation by jaguars. The Journal of Wildlife Management, 71, 2379-2386.

Berkes, F. \& FolKe, C. (200o) Linking social and ecological systems for resilience and sustaintability. In Linking Social and Ecological Systems: Management Practices and Social Mechanisms for Building Resilience (eds F. Berkes \& C. Folke), pp. 1-25. Cambridge University Press, Cambridge, UK.

Bezaury-Creel, J. \& Gutiérrez Carbonell, D. (2008) Áreas naturales protegidas y desarrollo social en México. In Capital Natural de México (eds J. Soberón, G. Halffter \& J. LlorenteBousquets), pp. 383-431. CONABIO, Mexico City, Mexico.

Bueno, A. (2004) Impacto del puma (Puma concolor) en ranchos ganaderos del área natural protegida "Cañón de Santa Elena", Chihuahua. MSc thesis. Instituto de Ecología, A.C., Xalapa Enríquez, Mexico.

Burgas, A., Amit, R. \& Lopez, B.C. (2014) Do attacks by jaguars Panthera onca and pumas Puma concolor (Carnivora: Felidae) on livestock correlate with species richness and relative abundance of wild prey? Revista Biología Tropical, 62, 1459-1467.

Carabias, J., Meli, P. \& Hernandez, G. (2010) Evaluación de los impactos de proyectos de desarrollo sustentable sobre la reducción del cambio de uso de suelo en ejidos de Marqués de Comillas, Chiapas. Universidad Nacional Autónoma de México, Instituto Nacional de Ecología, Mexico City, Mexico.

Caso, A., Lopez-Gonzalez, C., Payan, E., Eizirik, E., DE Oliveira, T., Leite-Pitman, R. et al. (2008) Panthera onca. In The IUCN Red List of Threatened Species 2008: e.T15953A5327466 [accesed 14 May 2015].

Chauvet, M. (2001) Los nuevos retos de la ganadería. In Historia ambiental de la ganadería en México (ed. L. Hernández), pp. 227-232. Instituto de Ecología A.C., Mexico City, Mexico.

Chávez, C. \& Ceballos, G. (2006) El jaguar mexicano en el Siglo XXI: situación actual y manejo. CONABIO, UNAM, Alianza WWF/ Telcel, Mexico City, Mexico.

Conforti, V.A. \& Azevedo, F.C.C. (2003) Local perceptions of jaguars (Panthera onca) and pumas (Puma concolor) in the Iguaçu National Park area, south Brazil. Biological Conservation, 111, 215-221.

Davies, J., Niamir-Fuller, M., Kerven, C. \& Bauer, K. (2010) Extensive livestock production in transition: the future of sustainable pastoralism. In Livestock in a Changing Landscape: Drivers, Consequences, and Responses (eds H. Steinfeld,
H.A. Mooney, F. Schneider \& L.E. Neville), pp. 285-308. Island Press, Washington, DC, USA.

De la Torre, J.A. \& Medellín, R.A. (2011) Jaguars Panthera onca in the Greater Lacandona Ecosystem, Chiapas, Mexico: population estimates and future prospects. Oryx, 45, 546-553.

De Vos, J. (1988) Oro verde. La conquista de la Selva Lacandona por los madereros tabasqueños, 1822-1949. Fondo de Cultura Económica, Mexico City, Mexico.

Donikar, R., Patil, V., Narkhede, S., Rane, A., Mokat, D. \& Bhave, S. (2011) Circumstantial and response attitudes of people affected with livestock depredation by leopards Panthera pardus Linnaeus in Ratnagiri District, Maharashtra, India. Journal of the Bombay Natural History Society, 108, 18.

FaO (Food and Agriculture Organization of the United NATIONS) (2009) El estado mundial de la agricultura y la alimentación, la ganadería a examen. FAO, Rome, Italy.

Garrote, G. (2012) Depredación del jaguar (Panthera onca) sobre el ganado en los llanos orientales de Colombia. Mastozoología Neotropical, 19, 139-145.

Gutiérrez, G. (1998) Estrategias de forrajeo. In Manual de Análisis experimental del comportamiento (eds R. Ardila, W. López, A. M. Pérez \& R. Quiñones), pp. 359-381. Librería Nueva, Madrid, Spain.

Hernández-Sampieri, R., Fernández-Collado, C. \& Baptista, P. (2008) Metodología de la Investigación. McGraw-Hill, Mexico City, Mexico.

Hoogesteijn, R. \& Arenas-Avella, R. (2008) Tópicos de sobre seguridad y abigeato en hatos ganaderos. In XXIII Cursillo sobre Bovinos de Carne (eds R. Romero, J. Salomón, J. De Venanzi \& M. Arias), pp. 21-58. Universidad Central de Venezuela, Facultad de Ciencias Veterinarias, Maracay, Venezuela.

Hoogesteijn, R. \& Hoogesteijn, A. (2008) Conflicts between cattle ranching and large predators in Venezuela: could use of water buffalo facilitate felid conservation? Oryx, 42, 132-138.

Hoogesteijn, R. \& Hoogesteijn, A. (2011) Estrategias anti-depredación para fincas ganaderas en Latinoamérica: una guía. PANTHERA, Campo Grande, Brazil.

Hull, V., Zhang, J., Zhou, S., Huang, J., Viña, A., Liu, W. et al. (2014) Impact of livestock on giant pandas and their habitat. Journal for Nature Conservation, 22, 256-264.

INe (Instituto Nacional de Ecología) (2004) Perspectivas del medio ambiente en México. GEO México, INE, PNUMA, SEMARNAT, Mexico City, Mexico.

Miller, K., Chang, E. \& Johnson, N. (2001) En busca de un enfoque común para el Corredor Biológico Mesoamericano. World Resources Institute, Washington, DC, USA.

Newing, H., Eagle, C., Puri, R.K. \& Watson, C. (2011) Conducting Research in Conservation: Social Science Methods and Practice. Routledge, New York, USA.

Palmeira, F.B., Crawshaw, Jr, P.G., Haddad, C.M., Ferraz, K.M.P. \& VERDADE, L.M. (2008) Cattle depredation by puma (Puma concolor) and jaguar (Panthera onca) in central-western Brazil. Biological Conservation, 141, 118-125.

Patton, M.Q. (2002) Qualitative Research \& Evaluation Methods. Sage Publications, Inc, Thousand Oaks, USA.

Peña-Mondragón, J.L. \& Castillo, A. (2013) Livestock predation by jaguars and other carnivores in Northeastern Mexico. Therya, 4 , $431-446$.

Ripple, W.J., Estes, J.A., Beschta, R.L., Wilmers, C.C., Ritchie, E.G., Hebblewhite, M. et al. (2014) Status and ecological effects of the world's largest carnivores. Science, 343, 1241484.

Rumiz, D.I., Polisar, J. \& Maffei, L. (2011) El futuro del jaguar en el Gran Chaco. Situación en Bolivia, Paraguay y Argentina. Wildlife Conservation Society, Santa Cruz, Bolivia. 
SANCHEZ, R. (2004) La observación participante como escenario y configuración de la diversidad de significados. In Observar, escuchar y comprender. Sobre la tradición cualitativa en la investigación social (ed. M.L. Tárres), pp. 97-130. Miguel Angel Porrua Editores, Flacso, El Colegio de la Frontera Sur, Mexico City, Mexico.

Sander, J.E., Warbington, M.C. \& Myers, L.M. (2002) Selected methods of animal carcass disposal. Journal of the American Veterinary Medical Association, 220, 1003-1005.

Schiess-Meier, M., Ramsauer, S., Gabanapelo, T. \& König, B. (2007) Livestock predation-insights from problem animal control registers in Botswana. The Journal of Wildlife Management, 71, 12671274 .

Semarnap (Secretaría de Medio Ambiente Recursos Naturales y Pesca) (200o) Reserva de la Biosfera Montes Azules. Instituto Nacional de Ecología, Mexico City, Mexico.

SEMARNAT (Secretaría de Medio Ambiente y Recursos Naturales) (2009) Programa de Acción para la Conservación de la Especie: Jaguar (Panthera onca). Secretaría de Medio Ambiente y Recursos Naturales, Ciudad de México, Mexico.

Sierra, F.C. (1998) Función y sentido de la entrevista cualitativa en investigación social. In Técnicas de investigación en sociedad, cultura y comunicación (ed. J.C. Galindo), pp. 277-346. Addison Wesley Longman, Mexico City, Mexico.

Soh, Y.H., Carrasco, L.R., Miquelle, D.G., Jiang, J., Yang, J., STOKES, E.J. et al. (2014) Spatial correlates of livestock depredation by Amur tigers in Hunchun, China: relevance of prey density and implications for protected area management. Biological Conservation, 169, 117-127.

Soni, C. (1998) Enfermedades que afectan a los terneros de destete precoz. Su prevención. Noticias y comentarios Instituto Nacional de Tecnología Agropecuaria, Estación Experimental Agropecuaria Mercedes, 324, 38-39.

Soto-Shoender, J.R. \& Giuliano, W.M. (2011) Predation on livestock by large carnivores in the tropical lowlands of Guatemala. Oryx, 45, 561-568.

Strauss, A.L. (1995) Qualitative Analysis for Social Scientists. Cambridge University Press, Cambridge, UK.

TArrés, M. L. (2004) Observar, escuchar y comprender. Sobre la tradición cualitativa en la investigación social. Región y Sociedad, 16, 209-213.

TAYLOR, S.J. \& Bogdan, R. (1987) Introducción a los métodos cualitativos de investigación. Paidós, Barcelona, Spain.
Thirgood, S., Woodroffe, R. \& Rabinowitz, A. (2005) The impact of human-wildlife conflict on human lives and livelihoods. In People and Wildlife. Conflict or Coexistence? (eds R. Woodroffe, S. Thirgood \& A. Rabinowitz), pp. 13-26. Cambridge University Press, New York, USA.

Tortato, F.R., Layme, V.M.G., Crawshaw, Jr, P.G. \& Izzo, T.J. (2015) The impact of herd composition and foraging area on livestock predation by big cats in the Pantanal of Brazil. Animal Conservation, 18, 539-547.

Van Bommel, L., Bij de Vaate, M.D., De Boer, W.F. \& De Iongh, H.H. (2007) Factors affecting livestock predation by lions in Cameroon. African Journal of Ecology, 45, 490-498.

Warman, A. (2001) El campo mexicano en el siglo XX. Fondo de Cultura Económica, Mexico City, Mexico.

Woodroffe, R. (200o) Predators and people: using human densities to interpret declines of large carnivores. Animal Conservation, 3 , 165-173.

Zarco-GonzÁlez, M.M., Monroy-Vilchis, O. \& Alaníz, J. (2013) Spatial model of livestock predation by jaguar and puma in Mexico: conservation planning. Biological Conservation, 159, $80-87$.

\section{Biographical sketches}

JUAN L. PENA-MONDRAGÓN is interested in the socio-ecology of large carnivores, and human-wildlife conflict. He works to develop measures to mitigate livestock depredation by large carnivorous mammals, involving local people in the conservation of species and the ecosystems they share with wildlife. AliCIA CASTILLO is interested in the social aspects of ecosystem management, with a particular focus on common pool resources and human-wildlife conflict. Almira HOOGESTEIJN is a veterinarian and has worked on wildlife conservation projects in the Americas and Europe for $>20$ years. Her main research focus is on the impact of pesticides and heavy metals on human and animal health, and stock management strategies to decrease predation. EnRIQUE MARTÍnEZ-MEYER is interested in understanding how environmental changes affect biodiversity, and how this pressure can be reduced. He has worked on global change biology issues, focusing on the application of ecological niche theory and methods, conservation biology, climate change and biogeography. 